Персида С. ЛАЗАРЕВИЋ DI GIACOMO* Università degli Studi "G. d'Annunzio" Chieti-Pescara
Оригинални научни рад

Примљен: 04. 12. 2019.

Прихваћен: 12. 02. 2020.

\title{
ЕНЦИКЛОПЕДИЗАМ ПЕКИЋЕВЕ ЗАТВОРСКЕ НАРАЦИЈЕ
}

\begin{abstract}
У овом раду се анализира енциклопедијска нарација антропопејске трилогије Борислава Пекића, Године које су појели скакавичи I (1987), II (1989), III (1990) - дело које се односи на године (1948-53), које је Пекић провео на издржавању казне у КПД у Сремској Митровици и Нишу. Теоријска заснованост приступа оваквом Пекићевом приповедању о робијању претпоставља резултате студија Менделсона (1976), Моретија (1994), Карла (2001) и превасходно Ерколина (2014) о тзв. максималистичком роману и енциклопедијској нарацији. Пекићево дело о којем је реч одговара истовремено бројним канонима и аспектима енциклопедијског приповедања и овом приликом се настоји да се уоквири морфолошки (али и симболички) идентитет Пекићевих успомена (из затвора), које су симболично посвећене „онима који нису били невини”, дакле свима. Тротомне успомене из затвора, максималистички и енциклопедијски препричане, потврђују атрибут који се приписује Пекићевом делу да је „океан и континент” наше и светске књижевности.
\end{abstract}

Кључне речи: Борислав Пекић, Године које су појели скакавци, енциклопедијски наратив.

Историји српске културе и књижевности је добро познато хапшење Борислава Пекића 1948. године:

Био сам члан илегалне студентско-гимназијске организације која се звала Савез демократске омладине Југославије. Ухапшен сам 7. новембра 1948. године а маја 1949. осуђен по Закону о кривичним делима против народа и државе, на првостепеном Окружном суду на 10 година, а потом ми је на Врховном суду, Народне Републике Србије 26. јуна 1949. године, казна повећана на 15 година затвора са присилним радом и извесним бројем година губитка грађанских права након издржавања казне. Помилован сам 29. новембра 1953. године (Красић-Марјановић 2010: 5).

Ако се изузме чињеница да је Пекић у својим делима обрадио разне аспекте затворског света, као нпр. у роману Како упокојити вампира (1977) где је приказао фигуру иследитеља или у Времену чуда (1965) где је у лику Јуде оформио „контролора”, о свом је затворском искуству у ствари строго

\footnotetext{
*persida.lazarevic@gmail.com
} 
ћутао све до 1987. кад је објавио прву књигу Година које су појели скакавци. Успомене из затвора или антропопеја (1948-1954) и кад је кренула бујица успомена које је једва успео да сажме у три тома (Пекић 1987, 1989, 1990). Као да је претходно сумњао у своју меморију јер, како каже, ,Чак и најкрвавијег рата човек се вољније сећа него свог затвора" (Пекић 1987: 27). Ту сумњу је подстакао

Мирко Ковач једне дуге, пријатне дубровачке ноћи. Као да паметнија посла нисмо имали, сећали смо се својих затвора. Ја, који сам по њима године провео, нисам о њима знао ништа нарочито да кажем. Ништа до неколико анегдота, које су већ толико понављањем прерађене да су се и мени самом чиниле - измишљеним. Његова је супруга, Боба Матић, ћутала као да је затворена била бар два пута дуже од мене. Мирко је с живошћу, убедљивошћу и импресивним даром запажања сатима говорио о свом затвору, својим робијама, на којима је провео - једну ноћ. Био је то још један доказ да време не постоји као нека фиксирана димензија. У његову затворску ноћ стале су туђе године, а моје године нису од те ноћи ни десетак минута стигле да узму (Пекић 1987: 27-28).

Не каже нам Пекић кад је то било, али несумњиво је да је после тог догађаја одлучио да добро испита затворски материјал и своју меморију и да од свог личног искуства уздигне ствари на универзални ниво и створи један текст за све, једну праву енциклопедију логоровања.

О енциклопедијском наративу је писао Менделсон још 1976, у два наврата, кад је указао на тадашњу непризнатост овог жанра у западној култури, а који у ствари сматра ексклузивом књижевности Запада, практично најважнијим жанром (Менделсон 1976а: 1267). Да би једно дело могло да се сматра енциклопедијским, по Менделсону мора да поседује извесне карактеристике и то конкретно: да представља једну широку синегдоху знања које је произвела извесна култура, да изнесе, у сажетом облику, доприносе барем једне науке или технологије, да претпостави многострукост жанрова и стилова, затим да се односи на уметности које нису књижевност, да изнесе историју језика и изнад свега да заузима централно место у књижевном систему из кога потиче. Менделсонова теорија је била и остала веома утицајна, па тако можемо да наведемо бројна друга дела која прате овај ток истраживања као Леклер (1989), Кларк (1990), Морети (1994), Карл (2001), Стрекер (2006), Ван Евијк (2011), или пак Ерколино (2014). Менделсонова теорија, међутим, има својих проблематичних тачака које потичу из ригидности тако постављеног теоријског модела, али и из захтева да дело буде централно у извесној културној средини. Такође је проблематично то што би аутор енциклопедијског дела требало да пружи историју језика. Менделсон је утицао на Франка Моретија (1994) да ову врсту дела назове „дело као свет” (,opera mondo”; уп. Колети 2011 који говори о „де-локализацији” романа) имајући тиме на уму дело које је космолошко, транснационално по својој структури и тематици, сложено и заокружено, глобално и глобализирајуће, полисемантичко. Берн (2007) је, пак, дао дефиницију „енциклопедијског романа”, а Карл (2001) истакао како ови „мега романи” узрокују „океанско искуство” код читаоца, што нашег, пак, читаоца подсећа управо на атрибут „океан” који Михајло Пантић (2002: 180) приписује Пекићу: „Његово [Пекићево] дело, по обиму, дубини 
и вредности готово да заснива целу једну самосталну књижевност, океан и континент на прастарој и несамерљивој планети писања.”

Можда до сада најцеловитија студија (Ребора 2006: 527) о овој врсти наратива долази из пера Стефана Ерколина (2014), који је роман енциклопедијског наратива назвао „максималистичким” и који је, истини за вољу, декласирао енциклопедијски роман са жанра на модалитет (или модус, како гласи превод једног Ерколиновог чланка на српски, в. Ерколино 2016) и оцртао морфолошки и симболички идентитет оваквих дела тиме што је навео десет елемената који енциклопедијски роман дефинишу као такав: 1) дужина, 2) енциклопедијски модус, 3 ) дисонантна масовност, 4) дијегетска претераност, 5) довршеност, 6) приповедачева омнисцентност, 7) параноична машта, 8) интерсемиотичност, 9) етичко залагање, 10) хибридни реализам (Ерколино 2015: 13). Наравно да овим Ерколино обухвата истовремено и неке аспекте које Карл сматра парадоксалним, као нпр. довршеност, кад каже да је мега-роман пун парадокса, да је дугачак, али му недостаје сваки смисао довршености (Карл 1983: 155) и штавише, карактерише га хаотичност (исто: 495-496).

Ерколино (2015: 56), дакле, истиче да је писање једног енциклопедијског дела не само могуће, „већ представља праву и стварну потребу, и на тај начин на себе преузима конотације изузетне утопијске вредности.” Енциклопедизам се рађа, прецизира Ерколино (исто), „као одговор на сталну и несигурну претњу уништењем, енциклопедизам који се тако представља као последњи бастион против апокалипсе: велика архива у стању да сачува знање од могућих катастрофа и гарантује реконструкцију света после катаклизме.” Та реконструкција света почиње у Пекићевом случају од његовог „повратка у затвор” чиме отвара своју нарацију, кад се сећањем враћа у „цивилизовану установу”, како каже, „за преодгајивање посрнулих или асоцијалних грађана, што су по природи и сврси, уосталом, и сви затвори на свету" (Пекић 1987: 12). У ствари Пекић додаје да је то „враћање затвора у мене” (исто: 23), нека врста „Великог спремања” које би значило „избацивање из живота свега што је утрошено и непотребно". То, међутим, код нашег аутора не постаје само отпад, није тек терапеутско избацивање ствари, већ од непотребног постаје потребни материјал за грађење једне праве енциклопедије робовања која тако постаје корисна свима, целом човечанству, ама баш свима који се овог тротомног романа лате. Материјал који је својствен Пекићу, али који је требало уздигнути на виши, универзални ниво.

Имао је у томе Пекић претходнике, као нпр. Борхеса: Борхесова енциклопедијска машта (Бел-Вилада 1999: 261) га је водила до тога да је измишљао чињенице и у суштини писао лажне енциклопедијске натукнице, описивао немогуће светове, или је пак писао есеје о Авероу и о Розенкројцерима, а да ништа о њима није прочитао, практично је од тек неколико података креирао културне ситуације које су не тако ретко одговарале стварности, такорећи визионарски. Нечег борхесовског има и у Пекићевој одлуци да пише о затвору у коме је он истовремено главни јунак и свезнајући наратор: 
Имао сам угодан али и паничан осећај да почињем нов роман који ће се од других разликовати једино у природи коришћених „факата живота” и у степену моје моралне обавезе према њима. (Трансформација тзв. факата живота у доброј књижевности последица је уметничке нужде и признат поступак технологије. Од нас се очекује да говоримо истину како смо је видели, а не како је најпогодније да је видимо, како је истину најбоље видети па да се остави најповољнији утисак.) [...] поштовање факата живота екслузивно почива на особном виђењу онога што се у њима и с њима догађа. [...] То што ће се у књижевности прича тек догодити, и што се, док се не догоди, може мењати - премда се стварно може мењати кад год нам се прохте - а у животу се већ догодила, па неприменљива изгледа, нема значаја.

Сећање и јесте ту да причу мења (Пекић 1987: 21-22).

Истовремено, међутим, истиче Пекић (1987: 23), та се затворска прошлост не разматра кроз уметнички поступак већ историографски. Ово комплетно, свеобухватно подучавање о робовању и о тоталитарним друштвеним системима, има своје порекло у значењу самог термина „енциклопедија”, на

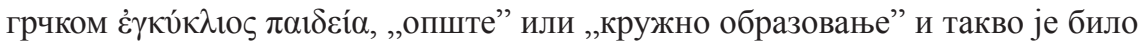
образовање кроз векове, почев од Плинија до хеленистичких и средњовековних енциклопедија које су звали Imago Mundi или Speculum mundi, па до Дидроове енциклопедије те данашњих енциклопедија, којима се настојало и настоји се да се знање уреди и да се остави у аманет људској раси. Па иако се Пекићева затворска енциклопедија односи у суштини на временски кратак период, од 1948-1954, то је било више него довољно аутору да пружи основу за дијахроно и синхроно, енциклопедијско свеобухватање робовања и режима. То јесте онда синегдоха логора која по бројним аспектима, укључујући и дужину (Ерколино 2015: 43-52), свакако задовољава услове енциклопедијског наратива.

А сам енциклопедијски модус или модалитет је, конкретно код Пекића, условљен потребом да се људској раси остави што је могуће потпунији запис о логорској цивилизацији. То је, каже Ерколино (2015: 56), суштинска потреба писања једног енциклопедијског или максималистичког дела које на тај начин добија на вредности утопије. То је оно што се Пекић стално пита: да ли године проведене на робији поједу скакавци или не, па се овај роман претвара у егзистенцијалистичку и антрополошку анализу времена. А ако знамо да управо Библија представља стални подтекст и интертекст свих Пекићевих дела па и Скакаваца, онда је била неизбежна и фундаментална метафора скакаваца који су присутни у Старом и Новом Завету, почев од Егзодуса па до Апокалипсе, тј. Јовановог Откровења те у Псалмима, и уопште у патристичкој литератури. Скакавци представљају универзалну катастрофу (Нацаро 2010: 93), па је стога универзално и ово Пекићево настојање да формира енциклопедију логорске катастрофе и њеног преживљавања. А то бесмислено трошење времена на крају трећег тома наводи овог аутора да изведе паралелу између робије и социјалистичког живота (Пекић 1990: 610), како је већ описао: 
Изведен из индивидуалне у општу, антрополошку раван, удружен са сродним судбинама, затворски је живот, с дугом и славном повешћу од Јосифове јаме до Сремске Митровице, открио наједном застрашујућу сличност с историјском реализацијом једне прогресивне друштвене утопије. Успомене ми више нису говориле о мом затворском животу. Саопштавале су ми универзалну причу о нашој промашеној верзији хуманитета.

Напор се није исплатио. Бојим се да се у затвор није ваљало враћати. Једна је робија сваком човеку довољна. Тим пре што је моја лакша била од сећања на њу. Тек сад сам одлежао ону праву и тек сад сам разумео властиту мисао из предговора Скакавцима:

Затвор је прележана болест која нас је у живот вратила с амнезијом ако нас је вратила - живе; с добром меморијом ако нас је убила.

Ерколино (2015: 61) сматра да се енциклопедијска дела рађају континуирано и да вероватно неће престати да се рађају, из потребе за илузијом да је могуће уредити и контролисати хаос и лудост постојања. Описујући енциклопедијски модус, Ерколино наводи карактеристике таквог начина писања, као нпр. сумирање, као нека врста потребе да се уреди и контролише хаос, а што је сложенији свет, то је веће настојање да се он представи и уреди. Пекић је уистину направио или барем настојао да направи што је могуће доследно сређену композицију затворског хаоса и режима. Но свакако да што су ствари сложеније, то је теже правити синтезу, и чини се као да Пекићу то успева, али некако мучно. Мучно у смислу да се добија утисак непрекидно мучног, болног покушаја синтезе, константног започињања и окончавања урамљивања факата и меморије коме се затворска материја стално опире, што због своје инхерентно хаотичне природе што због безбројних детаља којима треба наћи неки оквир, да би се опет почело изнова: чини се да Пекић, у тренутку када се одлучио да пише о робији, не жели да пропусти ништа, ама баш ништа, да непрестано покушава да свеобухвати обиман материјал који изискује исто толико невероватан напор. Ерколино (2015: 59) то потврђује: „Сврха било којег енциклопедијског дела је синтетичка нарација о укупности стварности. Разлика између енциклопедизма античког епа и енциклопедизма XX века није бити у промени функције, већ у умножавању и диференцијацији енциклопедијских покушаја.” У том умножавању енциклопедијских покушаја Пекићев напор је усредсређен ка томе да омнисцентно доминира наративни материјал који се тако манифестује као стална микро и макроструктурална игра, и тек се кроз парцијалну и истовремено целокупну визију долази до смисла приповедања (Ерколино 2015: 168), па тако Пекић и каже:

О затвору је немогуће говорити као о искуству које се исцрпљује једним судом, осећањем, односом. Јединственим сећањем које би га целог обухватило као што огледало прима и враћа сав наш лик. Затвор се кроз памћење, које му се саможиво опире, враћа као неодређена, безоблична нелагодност, сва слабија и аморфнија уколико је хронолошки даљи, сва снажнија, па и халуцинантна, ако нам затварање поново прети (Пекић 1987: 25).

И управо као нека врста фетиша, енциклопедијски модус садржи у себи опсесију детаљом (Ерколино 2015: 74), па Пекић непрестано, у тренутку кад је откључао врата своје меморије, доноси бројне детаље свог затворског сећања. Тако друга књига Скакаваща обилује бројним историјским и документарним детаљима, као нпр. у поглављу „Досије К-147/49. као археолошко откриће” (Пекић 1989: 23-33) који „представља основну грађу за књигу” 
(исто: 27) јер, како иронизује аутор, „Докуменат вреди само колико уме да се исправно прочита” (исто: 26) и одмах додаје горко: „Циљ књиге је исправно читање једног јединог судског документа, уз помоћ других, а највише уз подршку још живих успомена на време у коме је састављан."

То све манифестује једну изузетну и сложену когнитивност и ерудицију и Пекић почиње од митова и од Хомера, чиме потврђује своју припадност енциклопедизму максималистичког романа. Пре свега се свакако ради о томе да константно наводи и позива се на бројне наслове који су му послужили као секундарна литература за тему логоровања и диктатура: неизбежни Кафкин Прочес, затим Грешник Добрице Ћосића, Робије Оскара Давича, Помрачење y подне Артура Кестлера, Солжењицинов култни Архипелаг Гулаг, Прича о Колдииу (немачком казамату максималне сигурности у време другог светског рата) Пата Рејда, Седми крст Ане Зегерс, Папијон Хенрија Шарјера, такође неизбежни и „сјајни” (Пекић 1987: 154) Левитан Витомила Зупана, мемоари Власт Милована Ђиласа, Завера ћутања Вајсберга-Цибулског и др. Такође, бројне су референце које се односе на социолошка и антрополошка или пак футуристичка питања, као Поетика простора Гастона Башелара, Цивилизација класичне Европе Пјера Шонија, Магија, наука и религија Малиновског, Римска циивилизащија Пјера Гримала, али и Народни учитељь Васе Пелагића, Хакслијев Сетни Кром, Кроника култа личности Јевгеније Гинзбург.

А кад видимо колико се Пекић интертекстуално и интратекстуално позива на своја дела као нпр. Како упокојити вампира, 1999 и Златно руно, онда нам је више него експлицитна оваква наративна и информативна хипертрофија коју контролише чак и анахроно. Структура Пекићевог максималистичког енциклопедијског романа је таква да се, и тиме што обухвата скоро сва Пекићева претходна дела, може еволутивно, формално и садржајно сматрати „окончаним књижевним производом” (Ерколино 2015: 158) који следи презицну логику сређивања наративне грађе.

Пекић уздиже затворску цивилизацију на виши, универзални ниво којим се постиже метафора живота и питање о времену које се (узалудно) троши. Пекићева енциклопедијска амбиција онда представља естетску утопију, како каже Ерколино (2015: 81), да се прикаже тоталитет стварности. И управо тај тоталитет би спасао аутора од бесмислености година које су онда појели скакавци.

Зато Пекићев роман и носи поднаслов „антропопеја” и зато се Пекић и ослања на Свето писмо, митологију, класичну литературу, антропологију, социологију, историју, теологију, онтологију, па тако поставља кантовско, егзистенцијалистичко питање у поглављу „Тамничко небо нада мном и морални закон у мени или где је на робији ђаво а где Господ Бог” (Пекић 1990: 241), или пак пише праву есејистичку енциклопедијску литературу, као на примеру следећих поглавља из првог тома који су, суштински, есеји који карактеришу не тако ретко енциклопедијске романе: „Трактат о нужди” (123-142) и „Кратак компендијум људског усавршавања или Прича о стандардном минимуму” (301-317), док трећи том садржи праве „мале енциклопедије”: „Мала енциклопедија античког и средњовековног тамновања” (45-57), „Мала ен- 
циклопедија тамновања доба разума” (58-64), „Мала енциклопедија балканског и српског тамновања” (65-69), „Типологија затворских доушника и доушника на слободи” (251-265), „Морфологија затворских митова и култова и друштвени обичаји тамнице” (467-479), „Енциклопедија робијашке смрти” (539-541), „Затворске карактеристике социјалистичке слободе” (584-610). И на овај начин Пекић потврђује свој енциклопедизам: присуство разноврсних стилова и жанрова, обједињени тиме што су написани у прози, пружају увид у стилско богатство Пекићеве максималистичке, океанске, хибридне и енциклопедијске нарације.

На крају трећег тома, у поглављу „Године које нису појели скакавци”, Пекић каже за ову „аутобиографску творевину” (Пекић 1990: 611) да понавља „готово довршену” властиту прошлост и истовремено налази врлине и мане, но да и даље главно питање остаје време и да је тек на крају књиге схватио

да се књига пише можда и стога да се докаже како претпоставка из њеног наслова о ГОДИНАМА КОЈЕ СУ ПОЈЕЛИ СКАКАВЦИ није сасвим истинита, да је истина ова стављена у врх поглавља, по којој скакавци те године нису појели.

Веле да време које остави трага не може бити бесмислено. Бесмислено не може бити, дабоме да не може чим се живи, но, шта му брани да буде узалудно? Поготову тешко. А најпре, и узалудно и тешко (Пекић 1990: 619-620).

Рекло би се да то време није било узалудно ако је, као узрок или подстрек омогућило да Пекић напише енциклопедију логоровања и тоталитарних режима и тиме, још једном, потврди централно место у књижевној и културној средини Балкана, Југославије и Србије. Ако Ерколино (2015: 177) сматра да је мотор максималистичке књижевне маште параноја као аутентична онтолошка и епистемолошка основа (исто: 184), и то на разним нивоима, онда се неизбежно мора закључити да производ такве маште у случају Пекића води ка пророчанској визији енциклопедијског наратива који одјекује у свакој генерацији. Овај енциклопедијски роман је monitus кога спречава да то буде и ван међа Балкана само зато што је написан на једном малом језику. Суспендован између факата, тумачења и утопије, ово максималистичко, енциклопедијско тротомно аутобиографско дело обраћа се сваком својом страном читаоцу, неки пут чак веома директно као када аутор каже: „Што сам на слободи, а ви још нисте ухапшени чиста је срећа коју не треба изазивати.”

Пуни чињеница и историје, Скакавци су у непрестаном дијалогу са већ напоменутим другим Пекићевим делима, а својом сложеношћу комплементирају есенцијализам филозофског романа 1999. У „Прологу” романа 1999 Арно неизбежно и дистанцирано објављује: „Ако су Људи икада живели, ја сам Човек. / Јер, ја, Арно, знам шта је неизвесност" (Пекић 2001: 7). У Скакавцимма, пак, Пекић је страсно исцедио себе, своје сећање и своју енергију, да генерацијама људи које следе остави запис о логоровању, које се кроз историју у разним облицима понавља, и на тај начин пружи једно дефинитивно функционално дело које настоји да изложи нељудску извесност могућих друштвених система и логора које свако време потенцијално са собом доноси. 


\section{ЛИТЕРАТУРА}

Бел Вилада 1999: G H. Bell-Villada, Borges and his fiction: A guide to his mind and art, Austin: University of Texas Press.

Берн 2007: S. J. Burn, The Collapse of Everything: William Gaddis and the Encyclopedic Novell, y: J. Tabbi, R. Shavers (eds.), Paper Empire: William Gaddis and the World System, Tuscaloosa: University of Alabama Press, 46-62.

Ван Евијк 2011: P. Van Ewijk, Encyclopedia, Network, Hyper-text, Database: The Continuing Relevance of Encyclopedic Narrative and Encyclopedic Novel as Generic Designations, Genre 44/2, 205-222.

Ерколино 2014: S. Ercolino, The Maximalist Novel: From Thomas Pynchon's Gravity's Rainbow to Roberto Bolaño 2666, New York: Bloomsbury York.

Ерколино 2015: S. Ercolino, Il romanzo massimalista. Da l'Arcobaleno della gravità di Thomas Pynchon a 2666 di Roberto Bolaño, Milano: Bompiani.

Ерколино 2016: С. Ерколино, Енциклопедијски модус у модернистичкој и постмодернистичкој прози, Поља, LXI, 497, 128-140.

Карл 2001: F. R. Karl, American Fictions 1980-2000: Whose America Is It Anyway?, Philadelphia: Xlibris.

Кларк 1990: H. A. Clark, The Fictional Encyclopedia: Joyce, Pound, and Sollers, New York: Garland, New York.

Колети 2011: V. Coletti, Romanzo mondo. La letteratura nel villaggio globale, Torino: Einaudi.

Красић-Марјановић 2010: О. Красић-Марјановић, Борислав Пекић: 19301992, Београд: Општина Врачар, Библиотека града Београда.

Леклер 1989: T. LeClair, The Art of Excess: Mastery in Contemporary American Fiction, Urban: University of Illinois Press.

Менделсон 1976a: E. Mendelson, Encyclopedic Narrative: From Dante to Pynchon, Modern Language Notes, 91, 1267-1275.

Менделсон 1976б: E. Mendelson, Gravity's Encyclopedia, y: G. Levine, D. Leverence (eds.), Mindful Pleasures: Essays on Thomas Pynchon, Boston: Little, 161-195.

Морети 1994: F. Moretti, Opere mondo. Saggio sulla forma epica dal Faust a Cent'anni di solitudine, Torino: Einaudi.

Нацаро 2010: A. V. Nazzaro, Le locuste nella Bibbia e nella letteratura patristica latina, y: Il simbolismo degli elementi della natura nell'immaginario cristiano, Napoli: Edizioni Scientifiche Italiane, 85-112.

Пантић 2002: М. Пантић, Океан Пекић, у: Други о Пекићу, приредили Љ. Пекић, М. Пантић, Београд: Откровење, 180-183.

Пекић 1987: B. Pekić, Godine koje su pojele skakavci, uspomene iz zatvora ili antropopeja (1948-1954) I, Beograd: BIGZ.

Пекић 1989: B. Pekić, Godine koje su pojele skakavci, uspomene iz zatvora ili antropopeja (1948-1954) II, Beograd: BIGZ.

Пекић 1990: B. Pekić, Godine koje su pojele skakavci, uspomene iz zatvora ili antropopeja (1948-1954) III, Beograd: BIGZ.

Пекић 2001: Б. Пекић, 1999, Београд: Нолит. 
Peбора 2016: S. Rebora, Enciclopedismo e ipertestualità: tra indagine teorica e analisi empirica, y: Per Enza Biagini, a cura di A. Brettoni, E. Pellegrini, S. Piazzesi, D. Salvadori, Firenze: Firenze University Press, 525-535.

Стрекер 2006: T. Strecker, Narrative Ecology and Encyclopedic Narrative, y: L. Armand (ed.), The Avant-Garde Under Post Conditions, Prague: Litteraria Pragensia, 281-298.

Xayc 2000: R. House, The Encyclopedia Complex: Contemporary Narratives of Information, SubStance, 29/2, 25-46.

Persida S. Lazarević Di Giacomo

ENCYCLOPEDISM OF PEKIC'S PRISON NARRATIVE

(Summary)

This paper analyzes the encyclopedic narrative of Borislav Pekić's trilogy, Godine koje su pojeli skakavci (The Years the Locusts Devoured) I (1987), II (1989), III (1990) - a novel that describes the years (1948-53) Pekić spent serving his sentence at the prison of Sremska Mitrovica and Niš. The theoretical underpinning of such a Pekić's prison narrative presupposes the studies by Mendelson (1976), Moretti (1994), Karl (2001) and, above all, Ercolino (2014) on the so-called maximalist novel and encyclopedic narrative. Pekić's work, at the same time, corresponds to the many canons and aspects of encyclopedic storytelling, and seeks to frame the morphological (but also symbolic) identity of his memories (from prison), symbolically dedicated to "those who were not innocent", therefore to all. The three-volume prison memories, maximalist and encyclopedic, confirm the attribute of Pekić's work, i.e. the "ocean and continent" of Yugoslav, Serbian and world literature. 